\title{
KIAT MENINGKATKAN MINAT BELAJAR PESERTA DIDIK DALAM MATA PELAJARAN SENI BUDAYA MEMALUI MEDIA PEMBELAJARAN BERBASIS ICT
}

\author{
Ch. Dwi Anugrah \\ SMK Wiyasa Magelang \\ E-mail: anugrah_klg@yahoo.com
}

\begin{abstract}
Abstrak
Penelitian ini dilaksanakan dengan latar belakang rendahnya tingkat apresiasi seni kelas XI APh2 SMK Wiyasa Magelang. Yang menjadi fokus kajian di sini adalah kiat untuk meningkatkan minat belajar peserta didik melalui pembelajaran seni budaya dengan mengaplikasikan pembelajaran berbasis ICT. Penelitian ini bertujuan untuk mengetahui apakah metode pembelajaran berbasis ICT ini dapat meningkatkan minat belajar peserta didik dalam pencapaian batas penguasaan kompetensi dasar Apresiasi Seni Teater di SMK. Penelitian ini merupakan Penelitian Tindakan Kelas. Pengambilan data dalam penelitian ini dilakukan dengan menggunakan teknik observasi, wawancara, dan angket untuk data analisis kualitatif, serta penilaian hasil ulangan harian sebagai analisis data kuantitatif. Hasil penelitian bahwa menunjukkan melalui pembelajaran berbasis ICT terbukti dapat meningkatkan minat belajar peserta didik maupun pencapaian batas kompetensi dasar pada pembelajaran seni budaya khususnya materi Apresiasi Seni Teater peserta didik kelas XI APh2 SMK Wiyasa Magelang. Di samping itu pembelajaran berbasis ICT terbukti dapat menciptakan suasana pembelajaran yang menyenangkan serta menarik minat peserta didik, sehinga interaksi pembelajaran di kelas dapat diimplementasikan secara optimal.
\end{abstract}

Kata kunci : minat belajar, seni budaya, ICT.

\section{The Method of Increasing Students' Interest in ICT-Based Art and Culture Course}

\begin{abstract}
This research was conducted under the background of the low level of grade-XI students' appreciation of arts in SMK Wiyasa Magelang. The research focuses on the methods of increasing students' interest in learning through arts and culture course by applying ICT-based learning. Meanwhile, the aim of the research is to find out whether or not ICT-based learning can increase students' interest in learning, to be able to achieve the basic competences in Theater Appreciation in SMK Wiyasa Magelang. This research is a kind of action research. The data were taken by using the technique of observing, interviewing, ad giving questionnaire for gaining qualitative data, and analyzing the results of daily tests for gaining the quantitative data.The research results show that ICTbased learning can increase students' interest in learning and students' achievement of basic competences in arts and culture course, especially theater appreciation, among the students of Grade XI in SMK Wiyasa Magelang. Also, ICT-based learning can create fun and interesting learning activities so that learning interaction in class can be conducted well.
\end{abstract}

Keywords : learning interest, arts and culture, ICT. 


\section{PENDAHULUAN}

Bila ditelisik lebih mendalam sebagian peserta didik pada jenjang SMK merasa masih sangat asing dengan mata pelajaran Seni Budaya yang di dalamnya terdapat 4 materi baik itu seni rupa, seni tari, seni musik, dan seni teater. Fenomena tersebut dapat dimaklumi karena mata pelajaran ini termasuk mata pelajaran baru. Pemberlakuannya baru dimulai pada dua tahun berjalan ini, yang mengacu pada Standar Isi BSNP (Badan Standar Nasional Pendidikan) yang aplikasinya telah ditetapkan dengan Peraturan Menteri No. 22 tahun 2006. Standar Isi ini berisi pokok-pokok pembelajaran yang harus dikembangkan lebih lanjut oleh masing-masing satuan pendidikan dalam kurukulum yang dikenal dengan KTSP.

Keterasingan peserta didik pada mata pelajaran Seni Budaya ini sudah dipastikan menuntut kepiawaian guru sebagai pendamping untuk mengemas pembelajaran dapat semenarik mungkin, sehingga kejenuhan peserta didik dapat direduksi semininal mungkin. Kejenuhan peserta didik itu dapat ditengarai dari gaya mengajar guru yang membosankan ketika mengajar di depan kelas. Hal ini disebabakn guru tidak pernah mengevaluasi proses pembelajarannya di kelas. Dampaknya peserta didik tidak dapat konsentrasi, kemudian merasa jenuh, sebal, bahkan membuat ulah dan bikin gaduh. Kalaupun tampak mendengarkan, disebabkan karena faktor lain yaitu ketakutan. Akhirnya proses pembelajaran pun tidak dapat berjalan optimal seperti yang diharapkan.

Pembelajaran di sini mempunyai implikasi setiap aktivitas yang dirancang oleh guru untuk membantu seseorang mempelajari suatu kapabilitas dan nilai baru dalam suatu proses yang sistematis melalui tahap rancangan, pelaksanaan, dan evaluasi dalam konteks aktivitas belajar mengajar (Syaiful Sagala, 2007:64-65). Dalam proses pembelajaran tersebut dielaborasikan melalui pola pembelajaran yang menggambarkan kedudukan serta peran pendidik dan peserta didik dalam proses pembelajaran. Guru sebagai sumber belajar, penentu metode belajar, dan juga penilai progresifitas belajar meminta para peserta didik untuk menjadikan pembelajaran lebih efektif dan efisien dalam mencapai tujuan pembelajaran yang diharapkan.

Sebagai pemetaan, kondisi awal peserta didik SMK Wiyasa kelas XI Akomodasi Perhotelan 2 (APh2) tingkat apresiasi seninya masih rendah. Apresiasi seni dimaksudkan sebagai suatu kesadaran akan nilai-nilai seni untuk dapat memahami, menghayati, dan menghargai karya-karya seni sampai pada tingkat intensitasnya (Edy Tri Sulistyo, 2005: 7). Fenomena rendahnya tingkat apresiasi seni itu dapat dilihat dari gejala awal seperti berikut ini. Dari assesment awal yang diberikan kepada peserta didik kelas XI APh 2 yang berjumlah 35 atau sekitar $70 \%$ tidak mampu mendapatkan nilai 60 sebagai batas nilai ketuntasan. Hal itu diprediksi pembelajaran seni budaya di sekolah-sekolah menengah pertama (SMP) tempat peserta didik belajar sebelumnya masih mengacu pada model pembelajaran LDC (lihat, dengar, catat) yang berpusat pada guru, sehingga proses 
pembelajarannya menjadi terasa kering, tidak menyenangkan, dan membosankan bagi peserta didik.

Bila proses pembelajaran tersebut tidak bisa memberikan rasa nyaman maka keberhasilan peserta didik untuk belajar sudah dapat dipastikan tidak mungkin dapat optimal. Terlebih lagi bila guru mengaplikasikan metode pembelajaran ceramah dengan memposisikan dirinya menjadi subyek dan peserta didik hanya sekadar obyek, maka hasil yang didapatkan hanya sebatas sumber daya normatif konvensional yang menempatkan peserta didik dalam belenggu keterkungkungan. Oleh karena itu paradigma pendekatan pembelajaran seperti itu seharusnya sudah tidak digunakan lagi pada pembelajaran apresiasi seni di satuan pendidikan karena sudah tidak lagi sesuai dengan elaborasi peserta didik dan tuntuan zaman.

Dalam mengimplementasikan pembelajaran apresiasi seni bagi peserta didik pada satuan pendidikan lanjutan ada beberapa hal yang perlu diperhatikan, yaitu tingkat elaborasi peserta didik.Pada umumnya peserta didik tingkat SMK atau tingkat SLTA dan sejenisnya, pola pemikirannya masih berada pada tingkatan realis, mencoba-coba bereksperimen untuk mencari dan menemukan identitas dirinya. Dengan kondisi seperti itu maka pembelajaran apresiasi seni perlu dilakukan dengan pendekatan CTL (Contextual Teaching and Learning), yaitu suatu pendekatan untuk mendukung strategi pembelajaran yang sesuai dengan Standar Isi BSNP (Badan Standar Nasional Pendidikan) 2006 yang aplikasinya telah ditetapkan dengan Peraturan Menteri Nomor 22 tahun 2006. Standar Isi BSNP ini berisi pokok-pokok pembelajaran yang harus dikembangkan lebih lanjut oleh satuan pendidikan masing-masing dalam kurikulum yang dikenal dengan Kurikulum Tingkat Satuan Pendidikan (Susilo, 2007: 33-34).

Konsep pembelajaran yang bersifat kontekstual merupakan konsep yang membantu guru mengkorelasikan antara materi pembelajaran dengan situasi dunia riil peserta didik dan dapat mendorong peserta didik membuat korelasi antara pengetahuan yang dimilikinya dengan aplikasinya dalam kehidupan mereka sehari-hari.

Kesadaran perlunya pendekatan kontekstual dalam pembelajaran ini didasarkan adanya kenyataan bahwa dominasi peserta didik tidak mampu menghubungkan antara apa yang mereka pelajari dengan pemanfaatannya dalam kehidupan nyata. Hal ini karena pemahaman konsep akademik yang mereka peroleh hanyalah merupakan sesuatu yang abstrak, belum menyentuh kebutuhan praktis kehidupan mereka baik di lingkungan kerja maupun komunitas.

Pembelajaran yang selama ini mereka terima hanyalah penonjolan tingkat hafalan dari sekian rentetan topik atau pokok bahasan, tetapi tidak diikuti dengan pemahaman atau pengertian mendalam yang bisa diaplikasikan ketika mereka berhadapan dengan situasi baru dalam kehidupannya (Masnur Muslich, 2007: 41). 
Agar pembelajaran apresiasi seni berlangsung secara aktif, kreatif, inovatif, dan menyenangkan, maka proses pembelajaran perlu dibangun berdasarkan kegembiraan peserta didik dan guru. Di tengah-tengah keprihatinan terhadap lemahnya tingkat apresiasi seni peserta didik di SMK Wiyasa, penulis mencoba melakukan penelitian sederhana melalui metode pembelajaran dengan mengaplikasikan media pembelajaran berbasis ICT (Information and Communication Technology)

Mengapa menggunakan Metode ICT ? Salah satu kemajuan teknologi yang tidak bisa ditinggalkan dan sekarang ini adalah perangkat komputer. Pemanfaatan komputer pada berbagai ilmu pengetahuan, teknologi, dan seni telah terbukti dapat membantu segala aktivitas pekerjaan dapat efektif dan efisien. Hal itu dikarenakan elaborasi komputer sangat pesat, khususnya perangkat lunak (software) dan perangkat kerasnya (hardware).

Pemanfaatan perangkat lunak dan keras saat ini telah banyak digunakan dalam dunia pendidikan, tetapi karena keterbatasan kemampuan untuk mengaplikasikan, maka penggunaannya sebagai media pembelajaran belum bisa optimal. Padahal komputer potensi kegunaannya sangat besar sebagai media pembelajaran. Terutama untuk dapat meningkatkan minat dan animo peserta didik dalam mengikuti mata pelajaran yang diampu oleh guru masing-masing bidang studi.

Realita yang tidak bisa dinafikan menunjukkan, komputer sebagai pembelajaran di kelas masih jarang digunakan di jenjang pendidikan dasar sampai perguruan tinggi. Biasanya digunakan atas inisiatif guru yang secara personal atau lembaga tempat mengajar memiliki PC (Personal Computer) seperti notebook yang dihubungkan dengan LCD proyektor, yang berfungsi sebagai alat bantu utama untuk memvisualisasikan dan menstimulasikan materi pelajaran. Di samping itu komputer memiliki kelebihan bila dikomparasikan dengan media lainnya, misalnya mampu menyimpan, mengelola, dan menyajikan informasi serta mampu memvisualisasikan sesuatu dalam bentuk animasi, stimulasi, dan permainan. Dalam hal ini, penulis bermaksud meningkatkan motivasi minat belajar serta tingkat penalaran mereka dalam mata pelajaran seni budaya yang nantinya diharapkan dapat menjadi bekal untuk hidup di masyarakat. Penelitian ini dimaksudkan untuk mengetahui sejauh mana tingkat motivasi dan respek peserta didik terhadap mata pelajaran seni budaya dengan mengkomparasikan resultansi belajar mereka dalam dua siklus. Oleh karena itu, penulis merumuskan permasalahan dalam beberapa rumusan yaitu sebagai berikut : (1) Apakah pembelajaran dengan pendekatan sistem ICT ini dapat meningkatkan prestasi belajar peserta didik ?, (2) Apakah pembelajaran dengan mengaplikasikan media ICT ini dapat memberikan motivasi peserta didik untuk lebih berprestasi ? (3) Apakah melalui metode pembelajaran dengan menggunakan media ICT ini dapat menciptakan suasana pembelajaran apresiasi seni yang menyenangkan dan menarik minat peserta didik ? 


\section{TINJAUAN PUSTAKA}

\section{Pengertian Media}

Sebagai suatu model pembelajaran, media pembelajaran dengan model ICT sekarang ini merupakan model pembelajaran yang digandrungi peserta didik. Sementara untuk mata pelajaran yang belum tersentuh teknologi informasi banyak peserta didik yang cenderung tidak responsif, terlebih lagi kalau mata pelajarannya sulit dan gurunya killer.

Bila ditelisik dari etimologinya kata media berasal dari bahasa latin Medius yang secara harafiah berarti di tengah, perantara, atau pengantar. Adapun batasan umum implikasinya adalah segala sesuatu yang dapat dipergunakan untuk menyalurkan pesan yang dapat merangsang pikiran, membangkitkan semangat perhatian, dan kemauan sehingga dapat mendorong terjadinya proses pembelajaran pada diri peserta didik. Selain itu pemanfaatan media pembelajaran sangat berpotensi memberikan peluang bagi peserta didik untuk mengelaborasikan kepribadian (Angkowo, 2007: 10-11)

\section{Pemilihan Media Pembelajaran}

Pada dasarnya proses pemilihan media pembelajaran tidak sama dengan pemilihan buku pegangan dalam pembelajaran. Pemilihan buku pegangan perlu memperhatikankebutuhan dan kapabilitas peserta didik yang akan diajar. Sedangkan dalam memilih media pembelajaran, ada beberapa hal yang perlu diperhatikan :

1) Tujuan

Media yang dipilih hendaknya menunjang tujuan pembelajaran yang dirumuskan. Tujuan yang dirumuskan ini adalah kriteria yang paling pokok, sedangkan pembelajaran yang lain merupakan kelengkapan dari kriteria utama ini.

2) Ketepatgunaan

Jika materi yang akan dipelajari adalah merupakan bagian penting dari benda, maka gambar dan slide dapat digunakan. Apabila yang dipelajari adalah aspek-aspek yang menyangkut gerak, maka media film atau video akan lebih tepat. Adapun penggunaan bahan-bahan yang bervariasi akan dapat menghasilkan dan meningkatkan pencapaian akademik.

3) Keaadaan Peserta Didik

Media akan lebih efektif digunakan apabila tidak tergantung dari beda interindividual antara peserta didik. Misalnya kalau peserta didik tergolong tipe auditif/visual maka dapat belajar dengan media visual dan peserta didik yang tergolong visual dapat juga belajar dengan menggunakan media auditif

4) Ketersediaan

Walaupun suatu media dinilai sangat tepat untuk mencapai tujuan pembelajaran, media tersebut tidak dapat digunakan jika tidak tersedia. Media merupakan alat belajar mengajar, peralatan tersebut harus tersedia ketika dibutuhkan untuk memenuhi keperluan peserta didik dan guru.

5) Biaya 
Biaya yang dikeluarkan untuk memperoleh dan menggunakan media, hendaknya benar-benar seimbang dengan hasil-hasil yang akan dicapai.

Menurut Canei, R. Springfield, dan Clark,. C (1988: 62) dasar pemilihan alat bantu visual adalah memilih alat bantu yang sesuai dengan kematangan, minat, dan kapabilitas kelompok, memilih alat bantu secara tepat untuk kegiatan pembelajaran, mempertahankan keseimbangan dalam jenis alat bantu yang dipilih, menghindari alat bantu yang berlebihan, serta mempertanyakan apakah alat bantu tersebut diperlukan dan dapat mempercepat pembelajaran atau tidak.

\section{Learning Revolution}

Melalui pembelajaran yang manarik dan menggairahkan akan dapat memberikan magnet tersendiri kepada peserta didik untuk lebih berpusat pada pembelajaran Seni Budaya. Di samping itu dengan metode pembelajaran yang menyenangkan akan dapat mereduksi peserta didik pada tekanan-tekanan psikologis, sehingga kesan bahwa mata pelajaran Seni Budaya merupakan mata pelajaran yang membosankan dapat terjawab melalui pendekatan learning revolution ini.

Pembelajaran yang menyenangkan dapat diimplikasikan proses yang menyentuh seluruh komponen fisik dan non fisik yang terbebas dari tekanan. Dengan keadaan yang fun akan melapangkan dan mendayagunakan seluruh potensi secara optimal atau dalam bahasa lain keadaan yang akan mendorong bersungguh-sungguh, terlibat, dan asyik dalam melakukan sesuatu termasuk dalam belajar.

Adapun alasan-alasan dilakukannya model learning revolution dalam pembelajaran Seni Budaya di satuan pendidikan yaitu :

1) Belajar akan sangat efektif jika dilakukan dalam semangat yang menyenangkan.

2) Dengan menciptakan lingkungan belajar yang tepat, efektif, dan menyenangkan akan dapat mendorong pada pembelajaran yang mandiri.

3) Informasi yang kompleks dapat diserap dan diingat jika peserta didik benar-benar terlibat dalam proses pembelajaran.

4) Dengan pembelajaran yang sinergis dan terpadu akan dapat mengatasi berbagai ketinggalan informasi.

5) Belajar akan dapat tepat sesaran jika guru mampu mengkreasi ruang kelas seolah seperti dunia riil yang faktual.

Dengan learning revolution diharapkan dapat mempercepat pemahaman keilmuan secara efektif dan efisien, dalam rangka membangun masa depan pembelajaran kepada seluruh komunitas.

\section{Pembelajaran Berbasis Komputer}

Untuk mengatasi keterbatasan dan hambatan penggunaan media konvensional, perlu digunakan komputer sebagai alat bantu dalam pembelajaran. Dalam hal ini komputer lebih menarik dan efektif, karena dapat berinteraksi dengan peserta didik sebagaimana layaknya pembelajaran yang sebenarnya di kelas. Adapun kelebihan pembelajaran berbasis komputer ini adalah : 
1) Peserta didik bisa belajar secara invidu dan tidak malu kalau membuat kesalahan.

2) Tampilannya bisa menghasilkan kombinasi antara tulisan (teks), suara (audio), gambar (video), serta animasi.

3) Menghasilkan gambar yang lebih jelas.

4) Menyediakan akses informasi yang lebih banyak.

5) Dapat disesuaikan dengan motivasi, kemampuan, dan kecepatan peserta didik.

6) Mengurangi kekhawatiran pesera didik jika kurang paham terhadap materi.

Dengan mengaplikasin pembelajaran berbasis komputer ini diharapkan terjadi interaksi positif antara guru dan peserta didik sehingga pembelajaran semakin kreatif dan partisipatif.

\section{Belajar dan Motivasi Belajar}

Pada dasarnya konsep belajar merupakan komponen dalam ilmu pendidikan yang berkenaan dengan tujuan dan bahan acuan interaksi, baik yang bersifat eksplisit maupun implisit. Teori-teori yang dikembangkan dalam komponen ini meliputi antara lain teori tentang tujuan pendidikan, organisasi kurikulum, isi kurikulum, dan modul-modul pengembangan kurikulum. Kegiatan atau tingkah laku belajar terdiri dari kegiatan psikis dan fisik yang saling bekerjasama secara terpadu dan komprehensif. Sejalan dengan hal itu, belajar dapat dipahami sebagai suatu kiat atau usaha agar mendapat suatu kepandaian. Dalam implementasinya, belajar adalah kegiatan individu untuk memperoleh pengetahuan, perilaku, dan ketrampilan dengan cara mengolah bahan belajar.

Untuk menangkap isi dan pesan belajar, maka dalam belajar tersebut individu menggunakan kemampuan pada ranah-ranah: (1) kognitif yaitu kemampuan yang berkenaan dengan pengetahuan, penalaran, atau pikiran terdiri dari kategori pengetahuan, pemahaman, penerapan, analisis, sistesis, dan evaluasi; (2) afektif yaitu kemampuan yang mengutamakan perasaan, emosi, dan reaksi-reaksi yang berbeda dengan penalaran yang terdiri dari kategori penerimaan, partisipasi, penilaian/penentuan sikap, organisasi, dan pembentukan pola hidup; dan (3) psikomotorik yaitu kemampuan yang mengutamakan ketrampilan jasmani terdiri dari persepsi, kesiapan, gerakan terbimbing, gerakan terbiasa, gerakan kompleks, penyesuaian pola gerakan, dan kreativitas.

Akibat belajar dari ketiga ranah ini akan makin bertambah baik. Arthut T. Jersild menyatakan bahwa belajar adalah "modification of behavior throught experience and training" yaitu perubahan atau membawa akibat perubahan tingkah laku dalam pendidikan karena pengalaman dan latihan atau karena mengalami latihan. Belajar sebagai proses akan terarah kepada tercapainya tujuan (goal oriented). Dalam aspek ini dapat dilihat dari pihak peserta didik untuk mencapai sesuatu yang berarti bagi dirinya sendiri maupun guru sebagai tujuan. Belajar merupakan komponen paling vital dalam setiap usaha penyelenggaraan jenis dan jenjang pendidikan, sehingga tanpa proses belajar yang sesungguhnya tidak pernah ada pendidikan.

Belajar merupakan tindakan dan perilaku peserta didik yang kompleks. Berhasil atau gagalnya pencapain tujuan pendidikan amat tergantung pada proses belajar 
mengajar yang dialami oleh peserta didik dan pendidik baik ketika para peserta didik itu di sekolah maupun di lingkungan keluarganya sendiri.

Adapun belajar menurut pandangan B.F. Skinner (1958) adalah suatu proses adaptasi atau penyesuaian tingkah seseorang yang berlangsung secara progressif. Belajar juga dipahami sebagai suatu perilaku, maka responnya menjadi lebih baik pada saat melakukan aktivitas pembelajaran. Sebaliknya bila ia tidak belajar, maka responnya menjadi menurun. Jadi belajar adalah suatu perubahan dalam kemungkinan atau peluang terjadinya respon. Sebagai contoh, jika seorang anak belajar sungguh-sungguh, dengan demikian pada waktu diadakan uji kompetensi, peserta didik tersebut dapat menjawab semua soal dengan benar. Atas hasil belajarnya yang baik itu, ia akan mendapatkan nilai yang baik. Karena mendapatkan nilai yang baik ini, maka peserta didik itu akan belajar lebih giat lagi. Nilai tersebut dapat merupakan "operant conditioning" atau penguatan (reinforcement).

Dengan demikian suatu gagasan yang menyatakan bahwa belajar menyangkut perubahan dalam suatu organisme, berarti belajar juga membutuhkan waktu dan tempat. Oleh karena itu belajar dapat dikonklusikan dapat terjadi bila tampak tanda-tanda bahwa perilaku manusia berubah sebagai akibat terjadinya proses pembelajaran. Perhatian utama dalam belajar adalah perilaku verbal dari manusia, yaitu kapabilitas manusia untuk menangkap informasi mengenai ilmu pengetahuan yang diterimanya dalam belajar baik dalam ranah kognisi, afeksi, maupun psikomotorik.

Sedangkan motivasi belajar merujuk dari bahasa latin yaitu movere yang berarti dorongan atau daya penggerak. Bila dikaji lebih jauh motivasi mempunyai pengertian dorongan, kekuatan, atau mekanisme psikologi yang mendorong seseorang atau sekelompok orang untuk mencapai prestasi tertentu sesuai dengan apa yang dikehendakinya.

Motivasi memiliki dua komponen yang sangat signifikan, yaitu komponen dalam (inner component) dan komponen luar (outer component). Komponen dalam merupakan perubahan dari dalam diri sesesorang, keadaan merasa tidak puas, dan terjadi ketegangan psikologis. Komponen luar adalah apa yang diinginkan seseorang dengan tujuan yang menjadi arah kelakuannya. Bila ditarik suatu tautan benang merah komponen dalam merupakan kebutuhan-kebutuhan yang ingin dipuaskan, sedangkan komponen luar ialah tujuan yang hendak dicapai.

Dari uraian di atas secara eksplisit bisa dikaji bahwa motivasi dapat mendorong timbulnya perubahan tingkah laku. Jadi, motivasi mempunyai fungsi yang sangat dominan, yakni :

1) Mendorong timbulnya kelakuan atau perubahan. Tanpa motivasi maka tidak akan timbul sesuatu perbuatan seperti belajar.

2) Motivasi berfungsi sebagai pengarah. Artinya mengarahkan perbuatan untuk tercapainya tujuan yang diinginkan. 
3) Motivasi berfungsi sebagai penggerak. Ia berfungsi sebagai mesin bagi mobil. Besar kecilnya motivasi akan menentukan cepat atau lambatnya suatu pekerjaan.

Secara garis besarnya motivasi mengandung nilai-nilai dalam pembelajaran, di antaranya :

1) Motivasi menentukan tingkat berhasil atau gagalnya perbuatan belajar peserta didik. Belajar tanpa adanya motivasi kiranya sulit untuk berhasil.

2) Pembelajaran yang bermotivasi pada hakikatnya adalah pembelajaran yang disesuaikan dengan kebutuhan, dorongan, motif, minat yang ada pada peserta didik. Pembelajaran yang demikian sangat relevan dengan tuntutan demokrasi dalam pendidikan.

3) Pembelajaran yang bermotivasi menuntut kreativitas dan imajinasi guru untuk berusaha secara sungguh-sungguh mencari cara-cara yang relevan dan sesuai guna membangkitkan dan memelihara motivasi belajar peserta didik. Guru senantiasa berusaha agar peserta didik akhirnya memiliki self motivation yang baik.

4) Berhasil atau gagalnya dalam membangkitkan dan menggunakan motivasi dalam pembelajaran erat korelasinya dengan pengaturan disiplin di kelas. Kegagalan dalam hal ini mengakibatkan timbulnya masalah disiplin di dalam kelas.

5) Asas motivasi menjadi salah satu bagian yang integral daripada asas-asas mengajar. Penggunaan motivasi dalam mengajar bukan saja melengkapi prosedur mengajar, tetapi juga menjadi faktor yang menentukan pengajaran yang efektif. Dengan demikian penggunaan asas motivasi adalah sangat esensial dalam proses belajar mengajar (Oemar Hamalik, 2004: 159-162).

Sebagai fasilitator belajar, guru diharapkan dapat memantau dan memberi motivasi "tingkat kesulitan pengalaman belajar", dan segera membantu mengatasi kesukaran belajar peserta didik. Kiat membantu peserta didik tersebut dapat dilakukan dengan cara : (a) Peserta didik diberi tugas membaca bahan belajar sebelumnya; tiap membaca bahan belajar peserta didik disuruh mencatat hal-hal yang sukar. Catatan halhal yang sukar tersebut diserahkan kepada guru. (b) Guru mempelajari hal-hal yang sukar dari peserta didik. (c) Guru mencarikan solusi dari kesukaran peserta didik. (d) Guru memberi kesempatan peserta didik yang mampu memecahkan masalah membantu teman-temannya yang mengalami kesukaran. (e) Guru memberi penguatan kepada peserta didik yang berhasil mengatasi kesukaran belajarnya sendiri. (f) Guru menghargai pengalaman dan kapabilitas peserta didik agar belajar mandiri (Winkel, 1991: 110-119).

\section{Deskripsi Mata Pelajaran Seni Budaya}

Muatan mata pelajaran ini sebagaimana diamanatkan dalam Peraturan Pemerintah Republik Indonesia Nomor 119 tahun 2005 tentang Standar Nasional Pendidikan perlu diberikan di satuan pendidikan karena keunikan perannya yang tidak dapat diampu oleh mata pelajaran lain. Keunikan tersebut terletak pada pemberian pengalaman estetik dalam bentuk kegiatan berekspresi/berkreasi dan berapresiasi melalui pendekatan "belajar 
dengan seni," belajar melalui seni" dan "belajar tentang seni" yang terdiri dari cabang seni baik, seni pertunjukan, seni rupa, maupun seni media rekam

Pendidikan Seni Budaya memiliki tiga sifat yang sangat signifikan, yaitu multilingual, multidimensional, dan multikultural. Multilingual bermakna pengembangan kemampuan mengekspresikan diri melalui berbagai cara dan media. Multidimensional bermakna pengembangan beragam kompetensi meliputi konsepsi, apresiasi, dan kreasi dengan cara memadukan secara harmonis berbagai unsur baik estetika, logika, kinestetika, dan etika. Sedangkan sifat multikultural mengandung makna menumbuhkan kesadaran dan kemampuan apresiasi terhadap beragam budaya Nusantara dan Mancanegara. Hal ini merupakan wujud pembentukan sikap demokratis yang memungkinkan seseorang hidup secara beradab serta toleran dalam masyarakat dan budaya yang majemuk.

Di samping itu pendidikan Seni Budaya memiliki peranan dalam pembentukan pribadi peserta didik yang harmonis dengan memperhatikan kebutuhan perkembangannya dalam mencapai multikecerdasan yang meliputi kecerdasan intrapersonal, interpersonal, visual spasial, musikal, linguistik, logik matematik, adversitas, kreativitas, spiritual, serta moral.

\section{Ruang Lingkup}

Ruang lingkup penelitian tindakan kelas ini adalah Kiat Meningkatkan Minat Belajar Peserta Didik Dalam Mata Pelajaran Seni Budaya Melalui Media Pembelajaran Berbasis ICT kelas XI APh2 semester gasal SMK Wiyasa Magelang pada Tahun Pelajaran 2008/2009, dengan batasan-batasan sebagai berikut :

a. Mengacu kepada Standar Kompetensi yang tertulis dalam silabus khususnya materi cabang seni teater yaitu mengapresiasi karya seni teater.

b. Hanya dibatasi satu kompetensi dasar yaitu menunjukkan sikap apresiatif terhadap unsur-unsur estetis pertunjukan teater.

\section{Hipotesis Tindakan}

Dari hasil kajian praksis dan perpustakaan dapat ditarik suatu hipotesis tindakan sebagai berikut :

a) Proses pembelajaran dikatakan berhasil bila dalam pembelajaran terjadi peningkatan motivasi, kerjasama, dan prestasi bagi peserta didik

b) Paradigma pembelajaran yang menarik akan dapat meningkatkan prestasi peserta didik.

c) Pembelajaran materi Seni Budaya berbasis ICT akan mendorong peserta didik untuk lebih memahami materi dan dapat menstimulasi kreativitas, sehingga mereduksi kejenuhan dalam mengikuti pelajaran. 
d) Paradigma pembelajaran Seni Budaya berbasis ICT sangat menarik untuk dapat dipraktikkan pada mata pelajaran lain, guna dapat memberikan pengayaan imajinasi peserta didik, seperti menghadirkan dunia nyata di kelas.

\section{METODE PENELITIAN}

Penelitian ini termasuk jenis Penelitian Tindakan Kelas (PTK) yang ingin mengungkapkan kompetensi dasar apresiasi seni teater peserta didik melalui media pembelajaran berbasis ICT dan kondisi minat belajar mereka secara obyektif. Penelitian Tindakan Kelas (PTK) ini dilaksanakan pada tanggal 14 Juli 2008 sampai dengan 25 September 2008.

Adapun Subyek penelitian ini adalah Peserta Didik kelas XI APh2 SMK Wiyasa Magelang semester gasal Tahun Pelajaran 2008/2009. Prosedur PTK ini terdiri dari dua siklus. Tiap siklus terdiri dari kegiatan perencanaan, tindakan, observasi, dan refleksi.

Pengambilan data dalam penelitian ini dilakukan dengan menggunakan teknik observasi, wawancara, dan angket untuk data kualitatif, dan penilaian hasil ulangan harian peserta didik sebagai data kuantitatif.Untuk keperluan data kuantitatif diperoleh dari hasil ulangan harian yang dilakukan dua kali penilaian terhadap materi pembelajaran Apesiasi Seni Teater pada siklus I dan II. Untuk keperluan analisis data kualitatif diperoleh dari aktivitas pengamatan, wawancara, dan angket sebagai data non-tes. Observasi dilakukan oleh penulis untuk memperoleh gambaran secara obyektif kondisi selama proses pembelajaran berlangsung, serta mengamati sikap peserta didik selama tindakan penelitian dilakukan. Sedangkan kegiatan wawancara dan angket berguna untuk mengungkap tanggapan balik peserta didik dan dampak dari aktivitas tindakan selama proses pembelajaran berlangsung.

\section{HASIL DAN PEMBAHASAN}

Hasil penelitian ini diperoleh dari tindakan pada siklus I dan siklus II yang terealisasikan dalam hasil penilaiaan ulangan harian. Sedangkan hasil non-tes berupa pengamatan dan hasil wawancara pada siklus I dan II melalui angket yang sudah dipreparasikan.

\section{Deskripsi Kondisi Awal}

Dari pengamatan selama proses pembelajaran awal dari 35 peserta didik kelas XI APh2 SMK Wiyasa Magelang semester gasal tahun pelajaran 2008/2009 terlihat terasa jenuh dengan pelajaran Seni Budaya yang diberikan oleh guru. Hal itu dikarenakan tidak ada visualiasasi yang dapat memperkuat ranah imajinasi mereka terhadap materi yang sedang dipelajari. Walaupun guru sudah mempersiapkan diktat dengan visualiasai aktual di dalamnya, namun karena bukan dalam bentuk visualisasi hidup, maka materi tetap 
tidak dapat menumbuhkan sikap antusiasme peserta didik untuk dengan penuh totalitas mengikuti pelajaran yang berlangsung.

\section{Hasil Penelitian Siklus I}

Setelah mengikuti proses pembelajaran Seni Budaya dengan media pembelajaran berbasis ICT pada siklus I, diperoleh hasil ulangan harian seperti pada tergambar pada tabel 1 .

Tabel 1. Hasil Ulangan Harian Siklus I

\begin{tabular}{|c|c|c|}
\hline Nilai & Jumlah Anak & Persentase \\
\hline & 2 & 5,71 \\
$70-84$ & 11 & 31,43 \\
$70-79$ & 5 & 14,29 \\
$65-69$ & 6 & 17,14 \\
$60-64$ & 7 & 20,00 \\
$54-59$ & 4 & 11,43 \\
& & \\
\hline & 35 & \\
& & \\
& & \\
\end{tabular}

Pada tabel 1, peserta didik yang belum menguasai kompetensi dasar atau belum tuntas sejumlah 4 peserta didik atau sebanyak 11, $4 \%$. Sedang peserta didik yang telah mencapai kriteria ketuntasan minimal, yaitu dengan memperoleh nilai 60 sebanyak 31 peserta didik atau $78,4 \%$.

\section{Hasil Non Tes Siklus I}

Hasil pengamatan yang dilakukan pada siklus I diperoleh dari lembar pengamatan afektif yang mencakup materi : (1) Kehadiran, (2) Pro aktif bertanya, (3) Membaca referensi, (4) Elaborasi wawasan, (5) Partisipasi kegiatan presentasi, (6) Atensi peserta didik pada materi.

Resultansi yang cukup menggembirakan, bahwa ketika proses pembelajaran Seni Budaya berlangsung melalui pembelajaran berbasis ICT dengan menggunakan media LCD proyektor dan notebook, hampir semua peserta didik antusias dengan perasaan yang terpancar dari roman wajah mereka. Di samping itu bisa diamati, bahwa tingkat kesadaran mereka cukup tinggi untuk mengikuti proses pembelajaran yang sedang berlangsung. 
Untuk bisa lebih mendekatkan pada dunia kehidupan riil, penulis membuat visualisasi gambar yang diambil baik dari media cetak maupun elektronik. Sebagai misal kompetensi dasar materi yang mengulas bentuk teater, maka beberapa contoh bentuk teater yang ada di Indonesia baik itu tradisi maupun modern dapat disaksikan secara riil oleh peserta didik melalui visualisasi. Untuk lebih mendekatkan pada materi yang sedang dibahas, peneliti juga memutar beberapa repertoar musik yang relevan dengan isi materi. Dengan demikian proses pembelajaran bisa berlangsung dengan aktik, kreatif, inovatif, dan menyenangkan.

Adapun dalam siklus pertama ini yang perlu diperhatikan adalah masih belum adanya sikap percaya diri pada peserta didik untuk bisa tampil di muka publik dalam mengemukakan gagasannya. Di antaranya masih ada yang malu-malu ketika peneliti menyuruh mereka untuk menginterpretasikan sendiri beberapa visualisasi yang muncul di layar monitor LCD. Hal lain yang perlu mendapat perhatian yaitu ketika ada salah satu peserta didik yang presentasi di depan kelas ketika memberikan penguatan dari materi yang diberikan guru, ada beberapa teman yang menertawakan, padahal kalau dikaji tidak ada yang lucu dalam pembahasan materi tersebut. Untuk itu sikap keberamaan dan menghargai pembicara perlu lebih ditanamkan pada peserta didik.

Wawancara dilakukan bertujuan untuk mengetahui hambatan dan kemudahan yang dialami peserta didik dalam mengikuti mata pelajaran Seni Budaya melalui pembelajaran berbasis ICT.

Peserta didik yang tergolong dalam kelompok baik bependapat bahwa pembelajaran Seni Budaya melalui metode pembelajaran berbasis ICT sangat mengasyikkan, karena mereka merasa menemukan pembelajaran yang lain daripada yang lain, terutama dalam menerjemahkan kembali materi yang diberikan guru melalui paparannya sendiri. Menurut pendapat mereka, pembelajaran seperti ini dapat melatih kepercayaan diri selaku insan pariwisata untuk mampu menuangkan gagasan di depan publik.

Selain itu ada beberapa peserta didik yang dengan jujur mengatakan metode pembelajaran Seni Budaya berbasis ICT ini dapat membantu mereka dalam mengingat materi yang diberikan guru, karena dengan visualisasi mereka sepertinya dihadirkan dalam dunia riil yang ada di sekitarnya. Adapun peserta didik yang tergolong lemah berpendapat bahwa pembelajaran ini dapat menggugah semangatnya yang semula tidak antusias menjadi lebih bersemangat dan lebih pro aktif dalam mengikuti proses pembelajaran.

\section{Hasil Penelitian Siklus II}

Dalam tahapan siklus II ini penulis berusaha untuk mengkaji secara akuratif berbagai kesalahan tindakan yang terjadi pada siklus I untuk dapat diperbaiki pada siklus 
II. Adapun tahapan pada siklus II ini juga terdiri dari kegiatan perencanaan, tindakan, observasi, dan refleksi yang dirancang berdasarkan kesalahan, kelemahan, dan kekurangan yang sudah terjadi.

Upaya remedial yang memperhatikan aspek kesalahan, kelemahan, dan kekurangan pada siklus I, menghasilkan nilai ulangan harian seperti terlihat pada tabel 2

Tabel 2. Hasil Ulangan Harian Siklus II

\begin{tabular}{|c|c|c|}
\hline Nilai & Jumlah Anak & Persentase \\
\hline & & \\
$80-84$ & 5 & 14,29 \\
$75-79$ & 8 & 22,86 \\
$70-74$ & 7 & 20,00 \\
$65-69$ & 11 & 31,43 \\
$60-64$ & 4 & 11,43 \\
\hline & 35 & 100 \\
& & \\
\hline
\end{tabular}

Dari tabel 2 tergambar peningkatan ketuntasan belajar dari $78,4 \%$ pada siklus I menjadi $100 \%$ pada siklus II, karena seluruh peserta didik kelas XI APh2 yang berjumlah 35 anak telah memperoleh nilai 60 dan dianggap telah tuntas dalam menguasai kompetensi dasar materi Apresiasi Seni Teater.

\section{Hasil Non Tes Siklus II}

Pada dasarnya tindakan yang dilakukan pada siklus II hampir sama dengan kegiatan pada siklus I. Pada pembelajaran berbasis ICT siklus II ini lebih mengaksentuasikan pada intensitas pendalaman materi dengan lebih memperjelas visualisasinya. Di samping itu peserta didik didorong untuk lebih pro aktif dalam menanyakan beberapa materi yang belum jelas dan didorong juga untuk dapat mengutarakan gagasan terkait dengan materi Apresiasi Seni Teater yang sedang dipelajari.

Dari resultansi pengamatan pada siklus II diperoleh data bahwa 31 peserta didik atau $88,5 \%$ bersikap sangat antusias. Peserta didik mulai bertambah antusias mengikuti pelajaran dan mereka sangat pro aktif bertanya tentang materi yang belum dipahami. Selain itu mereka juga semakin percaya diri dalam mengemukakan gagasangagasan inovatif terkait dengan materi Apresiasi Seni Teater. 
Hasil wawancara pada siklus II dapat diamati dari peserta didik yang berkemampuan tinggi dan sedang menunjukkan adanya peningkatan sikap antusiasme mereka, karena mata pelajaran Seni Budaya ini bisa diimplementasikan lebih rileks dan menyenangkan. Hal itu ditunjukkan dengan peningkatan sikap kritis dan pro aktif mereka dalam mengikuti pelajaran. Di samping itu dari beberapa peserta didik yang berkemampuan rendah dapat digali informasi, bahwa materi pelajaran ini sangat komunikatif dan bisa menjadi contoh dari mata pelajaran lain yang selama ini masih dilaksanakan dengan konvensional dan menjenuhkan.

Hasil angket yang didistribusikan kepada sejumlah 35 peserta didik, dengan persentase 94,28 \% menyatakan sangat setuju bahwa metode pembelajaran Seni Budaya dengan menggunakan model pembelajaran berbasis ICT ini sangat menarik,mudah dipahami, lebih baik, dan sangat setuju untuk dilanjutkan penggunaannya.

Adapun sebanyak 5,71\% peserta didik menyatakan setuju. Dan tidak ada seorang pun peserta didik yang menyatakan tidak tahu, tidak setuju, apalagi sangat tidak setuju. Dengan demikian dapat ditarik suatu konklusi bahwa mata pelajaran Seni Budaya dengan menggunakan metode pembelajaran berbasis ICT sebagai model pembelajaran mendapat respon positif dari peserta didik.

\section{KESIMPULAN}

Metode pembelajaran berbasis ICT adalah pembelajaran menggunakan peralatan multi media yang dibangun berdasarkan kegembiraan peserta didik dan guru dalam rangka membantu dan memudahkan peserta didik untuk menghayati proses pembelajaran Seni Budaya khususnya kompetensi dasar Apresiasi Seni Teater yang berguna untuk meningkatkan kecerdasan emosional dan spiritual peserta didik.

Dibanding pembelajaran konvensional yang metode dan medianya terbatas, maka dengan aplikasi pembelajaran berbasis ICT, peserta didik mampu diajak untuk masuk ke dalam tiga ranah yang paling prinsip dalam pembelajaran, baik itu kognisi, afeksi, maupun psikomotorik.

Untuk mencapai kompetensi pada masing-masing ranah, pembelajaran berbasis ICT sangat membantu peserta didik. Dengan mengaktualisasikan pada visualisasi baik bentuk gambar, foto, tulisan, atau grafik dapat merangsang daya tangkap otak dan menarik dari perspektif estetika seni.

Melalui pembelajaran berbasis ICT terbukti dapat meningkatkan minat belajar peserta didik maupun pencapaian batas kompetensi dasar pada pembelajaran Seni Budaya. Di samping itu melalui pembelajaran berbasis ICT terbukti dapat menciptakan suasana pembelajaran yang menyenangkan Aplikasi mata pelajaran Seni Budaya melalu metode pembelajaran berbasis ICT dapat mengartikulasikan dan menyebarkan informasi 
nilai-nilai kekinian. Ia juga dapat memberi jalur alternatif bagi peserta didik menjadi lebih mempunyai jiwa humanis yang pada gilirannya dapat menyediakan preferensi dan sensitivitas akan potensi yang dimiliki peserta didik.

Harapan lebih jauh, pembelajaran berbasis ICT dapat menjadi trigger (pemicu) bagi guru untuk selalu belajar, memperbaiki metode pembelajarannya, serta mengkombinasikan alat bantu tersebut dengan pendekatan lainnya. Dengan penguasaan ICT pekerjaan guru dalam membuat desaian pembelajaran dapat dilakukan dengan lebih mudah, lebih cepat, dan lebih cermat. Tentu saja guru harus memiliki pemahaman tentang komputer dan memiliki ketrampilan untuk mengaplikasikannya.

Di samping itu diharapkan para guru mau dan bersedia membangun budaya tidak puas menggunakan satu metode tertentu saja, sehingga disarankan mengambil dari pengalamannya mengajar untuk menjadi kreatif guna menemukan dan menciptakan paradigma pembelajaran atau alat peraga baru sesuai dengan perkembangan jiwa peserta didik di sekolah.

Para guru dan peneliti lain dapat menindaklanjuti penelitian tentang teknik pembelajaran berbasis ICT ini dengan lebih fokus, variatif, dan mendalam,misalnya dampak lebih lanjut dari penggunaan media ICT, elaborasi teknik media ICT, faktorfaktor keberhasilan dan kekurangberhasilan peserta didik dalam menerima materi dengan media ICT, dan lain-lainnya.

Bagi peserta didik setelah mendapatkan materi pelajaran Seni Budaya berbasis ICT ini diharapkan untuk dapat lebih mengembangkan potensi dirinya, mengedepankan sikap pro aktif serta bersikap kritis yang membangun terhadap materi yang diberikan oleh guru sebagai pendamping

\section{DAFTAR PUSTAKA}

Achmad, A. Kasim. 1990. Pendidikan Seni Teater. Jakarta: Pendidikan dan Kebudayaan. Astono, Sigit. et al. 2006. Apresiasi Seni 3 "Seni Tari dan Musik”. Bogor: Yudhistira. Angkowo, R dan Kosasih, R. 2007. Optimalisasi Media Pembelajaran. Jakarta: Grasindo.

Anugrah, Dwi.,Ch. "Pertarungan Dua Festival Borobudur", dalam Majalah Gong Edisi 48/2003.

, "Wayang Orang Pembauran", dalam Dewan Kesenian Jawa Tengah.

2003. Direktori Seni Tradisi Jawa Tengah. Semarang: Dewan Kesenian Jawa Tengah.

, "Konser di Borobudur antara Profit dan Potensi Lokal", dalam

Kompas, 19 April 2005.

, "Eksploitasi Seniman Tradisi", dalam Kompas, 15 Juni 2005.

,"Mahakarya Borobudur Inspirasi dalam Bingkai Historis", dalam

Majalah Gong Edisi 74/VII/2005

,"Wayang Orang Sriwedari antara Kebesaran dan Keprihatinan", dalam

Kedaulatan Rakyat, 11 September 2005.

November 2005

"Kelemahan Manajemen Seni Tradisi", dalam Kedaulatan Rakyat,

,"Mata Pelajaran Seni Budaya", dalam Kompas, 10 Agustus 2006.

November 2006.

, "Kreativitas dan Krisis Empu Tari", dalam Kedaulatan Rakyat, 
, "Kiat Merekatkan Potensi Jaringan”, dalam Komunitas Lima Gunung. 2007. Budaya Lima Gunung Belum Tergantung Trias Politika. Magelang: Komunitas Lima Gunung

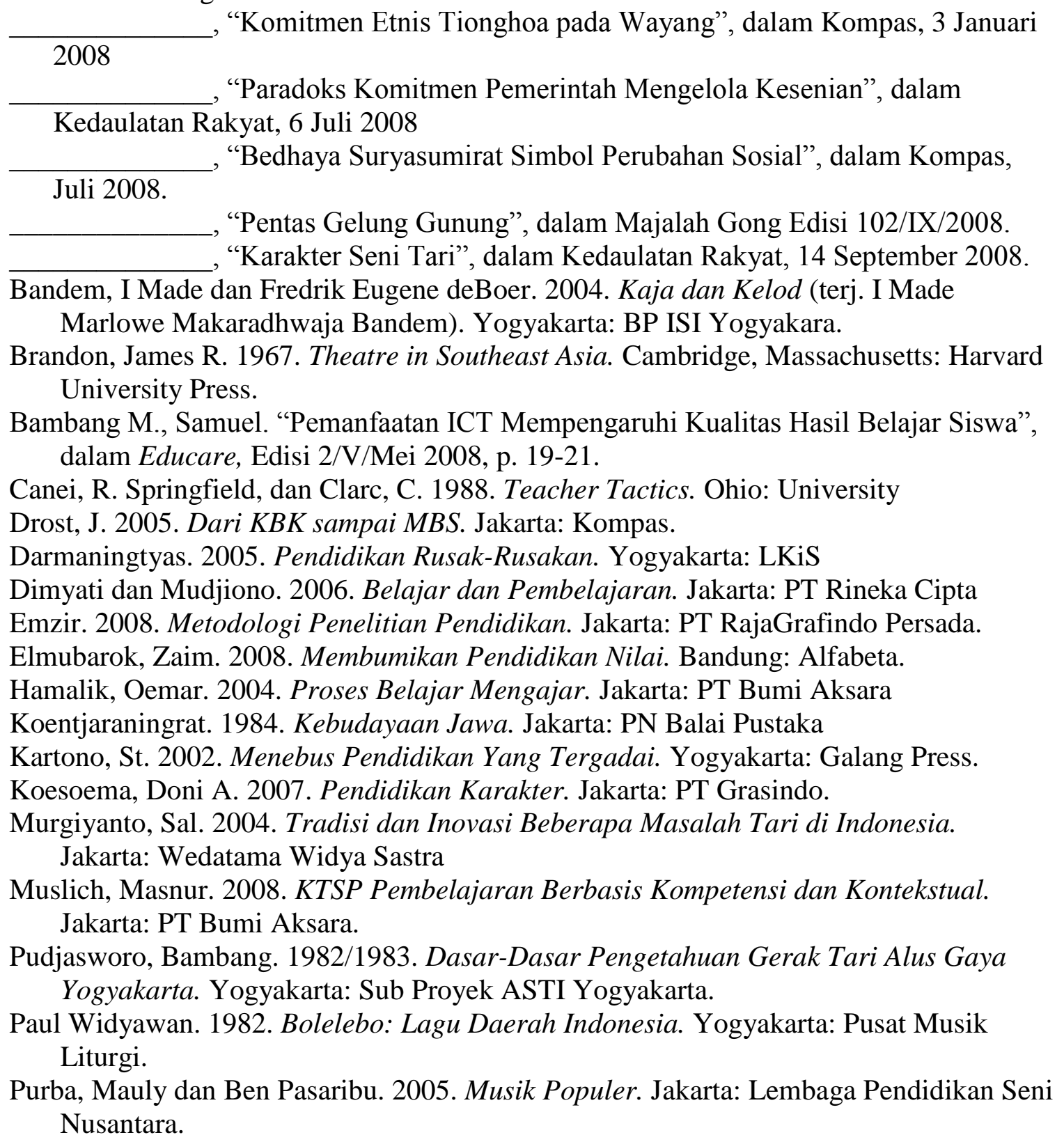

Sachari, Agus. 2007. Seni Rupa dan Desain untuk SMA Kelas X dan XI. Bandung: Erlangga.

Sedyawati, Edi. 1981. Pertumbuhan Seni Pertunjukan. Jakarta: Sinar Harapan.

Soedarsono. 1990. Wayang Wong: The State Ritual Dance Drama in The Court of Yogyakarta. Yogyakarta: Gadjah Mada University Press.

, 1999. Seni Pertunjukan Indonesia dan Pariwisata. Bandung: MSPI.

, 2003. Seni Pertunjukan dari Perspektif Politik, Sosial, dan Ekonomi. Yogyakarta: Gadjah Mada University Press.

Suanda, Endo dan Sumaryono. 2006. Tari Tontonan. Jakarta: Lembaga Pendidikan Seni Nusantara.

Soekmono, R. 1991. Pengantar Sejarah Kebudayaan Indonesia 2. Yogyakarta: Kanisius.

Soemaryono. 2003. Restorasi Seni Tari dan Transformasi Budaya. Yogyakarta: Elkaphi Prasista. 2007. Jejak dan Problematika Seni Pertunjukan Kita. Yogyakarta:

Sutrisno, Mudji., S.J. 1999. Kisi-Kisi Estetika. Yogyakarta: Kanisius.

Suparno, Paul, et al., 2002. Reformasi Pendidikan Sebuah Rekomendasi. Yogyakarta: Kanisius.

2005. Guru Demokratis di Era Reformasi. Jakarta: Grasindo.

Suyanto. 2006. Dinamika Pendidikan Nasional. Jakarta: PSAP Muhammadiyah.

Susilo. 2007. Panduan Penelitian Tindakan Kelas. Yogyakarta: Pustaka Book Publisher.

Setiawan, Beni. 2008. Agenda Pendidikan Nasional. Yogyakarta: Ar-Ruzz Media.

Sagala, Syaiful. 2008. Konsep dan Makna Pembelajaran. Bandung: Alfabeta. 
Tillar, HAR dan Nugroho, Riant. 2008. Kebijakan Pendidikan. Yogyakarta: Pustaka Pelajar.

Tri Sulistyo, Edy. 2005. Kaji Dini Pendidikan Seni. Surakarta: LPP dan UNS Press.

Uzer Usman, Moh. 2006. Menjadi Guru Profesional. Bandung: PT Remaja Rosdakarya. Widaryanto, F.X. 2002. Merengkuh Sublimitas Ruang. Bandung: STSI.

, 2007. Menuju Representasi Dunia Dalam. Bandung: Kelir.

Walgito, Bimo. 2005. Bimbingan dan Konseling. Yogyakarta: Andi Offset

Winkel. 2007. Psikologi Pengajaran. Yogyakarta: Media Abadi. 